\title{
Review Literatur Tentang Analisis Kepuasan Layanan dengan Pendekatan Servqual dan IPA
}

\author{
I Putu Astya Prayudha ${ }^{1}$, Made Sudarma ${ }^{2}$, Ida Bagus Alit Swamardika ${ }^{3}$ \\ [Submission: 01-04-2021, Accepted: 27-05-2021]
}

\begin{abstract}
One of the factors in business competition is the quality of service to customers. Every company must pay attention to the quality of services. Several factors determine whether a service is considered of good quality or not, namely internal and external. Ways to measure the quality of the service are for example the Service Quality and Importance Performance Analysis methods. This article discusses the use of the Service Quality method as well as the Importance Performance Analysis method that is applied in government and private institutions. The results show that the application of the servqual and IPA methods has been able to find which services are a priority for improvement in institutions or the private sector. The results of the analysis can also be seen that services at private institutions are better at providing satisfaction to their customers with a value of $63 \%$ compared to government agencies which can only provide a value of $51 \%$.

Keywords - Service, Service Quality, Importance Performance Analysis.
\end{abstract}

Intisari - Salah satu faktor dalam persaingan bisnis saat ini adalah kualitas layanan yang diberikan kepada pelanggan. Setiap perusahaan harus memperhatikan kualitas layanan yang diberikan. Beberapa faktor menentukan apakah suatu layanan dianggap berkualitas baik atau tidak yaitu dari internal dan eksternal. Cara untuk mengukur kualitas layanan tersebut misalnya dengan metode Service Quality dan Importance Performance Analysis. Artikel ini membahas penggunaan metode Service Quality serta metode Importance Performance Analysis yang diterapkan di lembaga pemerintah dan swasta. Hasil menunjukkan bahwa penerapan metode servqual dan IPA telah dapat menemukan layanan mana yang menjadi prioritas untuk ditingkatkan di lembaga atau swasta. Hasil dari analisis juga dapat dilihat bahwa bahwa layanan pada lembaga swasta lebih baik dalam memberikan kepuasan kepada pelanggannya dengan nilai $63 \%$ dibandingkan pada lembaga pemerintah hanya dapat memberikan nilai $51 \%$.

Kata Kunci- Layanan, Service Quality, Importance Performance Analysis

${ }^{1}$ Mahasiswa, Magister Teknik Elektro Universitas Udayana, Gedung Pascasarjana Universitas Udayana Jl. PB Sudirman Denpasar-Bali, Kode Pos: 80232;( telp/fax: 0361-239599; e-mail: yogiswara.dharma@student.unud.ac.id)

2, 3 Dosen, Program Studi Magister Teknik Elektro Fakultas Teknik Universitas Udayana, Jln. P.B. Sudirman, Denpasar, Bali 80232 INDONESIA (telp: 0361-239599e-mail: gusalit@unud.ac.id, msudarma@unud.ac.id)

\section{PENDAHULUAN}

Kualitas merupakan hal yang sangat penting didalam menjalankan sebuah bisnis. Semakin baik kualitas produk atau jasa yang diberikan oleh perusahaan maka perusahaan akan mampu dalam menghadapi persaingan bisnis yang saat ini semakin ketat. Persaingan dapat berupa persaingan pada bidang inovasi, teknologi, dan pelayanan. Persaingan dalam dunia bisnis yang menjadi prioritas yang harus diperhatikan oleh perusahaan adalah kualitas dari layanan yang diberikan.

Setiap perusahaan untuk dapat bersaing harus mampu menyediakan dan memberikan suatu layanan sesuai kebutuhan dan keinginan pelanggan. Semakin banyaknya persaingan saat ini maka perusahaan mau tidak mau harus dapat menyusun strategi sehingga tidak harus kehilangan pasar dan pelanggan nantinya.

Salah satu faktor yang mendorong tercapainya layanan yang baik yaitu kualitas dari layanan kepada customer / pelanggan. Kualitas layanan yang diberikan kepada pelanggan dimulai dari kebutuhan pelanggan dan berakhir pada persepsi pelanggan.

Semakin besar pangsa pasar yang didapat oleh sebuah perusahaan maka akan memperoleh keuntungan yang besar pula. Kunci keberhasilan dan dapat mempertahankan pasar tersebut yaitu dengan memahami lebih baik kebutuhan dan proses yang diinginkan oleh pelanggan termasuk layanan yang diinginkan.

Terdapat berbagai macam metode untuk mengetahui tingkat layanan pada sebuah perusahaan baik pada layanan operasional maupun layanan sistem yang digunakan diantaranya yaitu Service Quality, Web Quality, Customer Satisfaction Index (CSI), Importance Performance Analysis (IPA). Beberapa penelitian yang menggunakan metode servqual dan IPA dalam memperbaiki layanannya yaitu sebagai berikut. Penelitian yang dilakukan oleh Rachman dkk pada tahun 2018 dengan menggunakan metode servqual dan IPA dengan tujuan untuk mengetahui prioritas perbaikan layanan administrasi di Universitas Esa Unggul. Terdapat 22 layanan yang diteliti berdasarkan pada metode servqual. Setelah dilakukan proses pengelompokkan berdasarkan IPA maka diketahui tingkat layanan yang ada. Hasil dari IPA yaitu terdapat 4 atribut yang menjadi prioritas perbaikan layanan yang berasal dari dimensi reability dan dimensi emphaty dengan berfokus pada perbaikan layanan administrasi yang ada di Universitas Esa Unggul [1].

Gani dkk pada tahun 2020 melakukan penelitian untuk mengukur kualitas dari website VISLOG yang ada di PT. Citra Surya Indoensia. Penelitian ini bertujuanuntuk mengetahui tingkat dari layanan website terhadap pengguna. Penelitian dilakukan dengan menggunakan kuesioner dalam mendapatkan nilai layanan yang berdasarkan pada dimensi webqual. Hasil

p-ISSN:1693 - 2951; e-ISSN: 2503-2372 
dari penelitian menunjukkan bahwa layanan tingkat kinerja yang rendah atau dibawah rata-rata sehingga mempengaruhi harapan yang diinginkan oleh pengguna dari website [2].

Service Quality digunakan sebagai pemenuhan keinginan dari pelanggan serta ketepatan penyampaiannya untuk mengimbangi harapan pelanggan. Kekurangan dari metode Service Quality yaitu metode ini hanya menerjemahkan atribut pada layanan perusahaan kedalam dimensi Service Quality sehingga memerlukan metode perhitungan untuk mengolah hasil penilaian dari pelanggan. Web quality merupakan salah satu metode atau teknik pengukuran kualitas layanan khususnya pada website perusahaan berdasarkan persepsi pengguna. Kelemahan dari Web Quality yaitu dimensi berfokus kepada layanan website dan sama dengan Service Quality dimana harus membutuhkan metode tambahan dalam mengolah data dari pelanggan. CSI digunakan untuk mengukur kepuasan pelanggan secara keseluruhan dengan memperhatikan tingkat kepentingan dari atribut-atribut jasa maupun produk. Kelemahan dari CSI yaitu hanya dapat mengetahui nilai total tingkat kepuasan dari pelanggan dan CSI tidak dapat mengetahui atribut layanan mana yang harus diperbaiki. IPA merupakan teknik yang digunakan untuk mengalokasikan setiap atribut layanan kedalam diagram kertesius sehingga perusahaan dapat mengetahui atribut layanan yang perlu untuk diperbaiki. Metode IPA hanya sebagai metode transformasi atribut layanan kedalam diagram kertesius dan tidak dapat mengukur nilai tingkat layanan dalam perusahaan secara total atau keseluruhan.

Berdasarkan pada penelitian yang telah dilakukan diatas metode yang menurut peneliti perlu dibahas yaitu mengenai penggunaan dari metode yang menggunakan servqual dan IPA. Tujuan dilakukan penelitian ini yaitu mengetahui efektifitas dari penggunaan servqual dan IPA serta menemukan kelebihan dan kelemahan dari penelitian sebelumnya.

\section{KAJIAN PUSTAKA}

\section{A. Service Quality}

Servqual atau service quality ditemukan oleh peneliti Parasuraman, Berry dan Zeithaml pada tahun 1988. Metode servqual merupakan metode yang memperlihatkan perbedaan antara harapan dari pelanggan terhadap kinerja yang diberikan oleh perusahaan. Terdapat lima dimensi ukuran kualitas dari layanan diantaranya yaitu keandalan, daya tanggap, jaminan, bukti langsung, dan empati. Pengukuran yang dilakukan pada metode servqual ditentukan pada skala multi item yang dirancang dalam mengukur harapan pelanggan serta nilai saat ini dari pelanggan. Berikut merupakan kelima dimensi pada metode servqual.

1. Keandalan merupakan kemampuan dari perusahaan dalam memberikan layanan sesuai yang dijanjikan.

2. Daya tanggap merupakan keinginan dari penjual dalam melakukan respon terhadap pelanggan dengan cepat dan tanggap.

3. Jaminan yang mencakup pelayanan yang diberikan kepada pelanggan dengan sikap yang sopan sehingga memuaskan pelanggan.
4. Empati yaitu bagaimana penjual memahami pelanggan dan memenuhi semua kebutuhannya.

5. Bukti langsung yaitu fasilitas yang dimiliki oleh perusahaan.

\section{B. Importance of Performance Analisis}

Pendekatan dari IPA adalah metode atau cara analisis yang digunakan untuk mengetahui pengelompokkan atribut dalam organisasi dalam memenuhi kepuasan para pelanggan. IPA memiliki empat dimensi atau kuadran yang digambarkan pada tabel berikut.

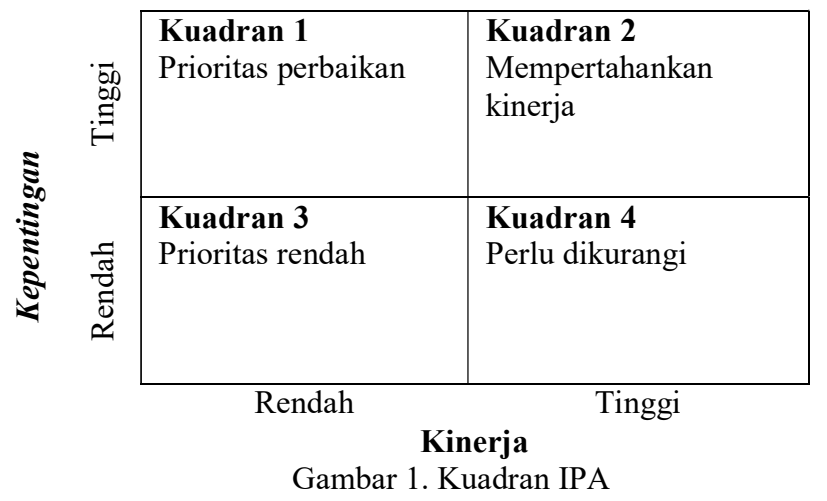

Kuadran 1 merupakan daerah yang menurut pelanggan sangat penting tapi pada kenyataannya masih belum sesuai dengan harapan yang diinginkan oleh pelanggan. Kuadran 2 merupakan daerah dari aspek yang penting dan telah memenuhi keinginan dari pelanggan sehingga perlu untuk dipertahankan. Kuadran 3 merupakan wilayah yang dianggap tidak sesuai dengan harapan tetapi dampaknya tidak terlalu berpengaruh pada pelanggan. Kuadran 4 merupakan daerah yang berisi atribut layanan yang kurang penting, sehingga dikatakan berlebihan. Atribut yang ada pada kuadran ini perlu untuk dikurangi agar dapat mengurangi biaya perusahaan [3].

\section{BAHAN DAN METODE}

Skematik penelitian yang dibahas pada penelitian ini dirancang dengan alur sebagai berikut.

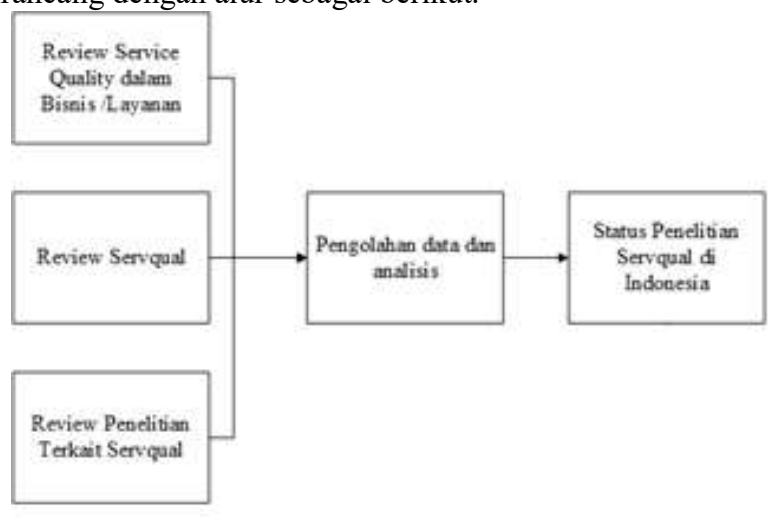

Gambar 2. Skematik Penelitian 
Majalah Ilmiah Teknologi Elektro, Vol. 20, No. 2, Juli-Desember 2021

DOI: https://doi.org/10.24843/MITE.2021.v20i02.P04

Penelitian dilakukan dengan melakukan review terhadap penggunaan metode servqual dalam bisnis atau layanan. Data review didapatkan pada penelitian yang diteliti sebelumnya dengan studi kasus pada lembaga pemerintahan dan swasta kemudian akan dilakukan pengolahan data dan analisis terhadap penelitian tersebut sehingga akan memunculkan status penelitian dan pengaruh metode servqual di Indonesia. Tujuan dilakukannya review pada penelitian ini untuk mengetahui alur proses penerapan metode servqual dan IPA dalam lembaga pemerintahan dan swasta.

\section{ANALISA DAN PEMBAHASAN}

\section{A. Penelitian dengan Metode Servqual dan IPA}

Winarno dan Absor membahas mengenai penerapan dari metode servqual dan IPA pada PT. MPE dimana penelitian ini bertujuan untuk mendapatkan tingkat kepuasan dari rekanan perusahaannya. Hasil penelitian ini menunjukkan bahwa layanan perusahaan dikatakan baik, namun masih terdapat satu atribut pada dimensi tangibles yang masih kurang dengan nilai gap -0,296 dan 1 dimensi responsiveness dibawah rata-rata yaitu dengan nilai $-0,185$. Perbaikan yang dilakukan untuk memperbaiki kekurangan tersebut yaitu mengadakan pelatihan kepada karyawan [4].

Penelitian yang dilakukan oleh Setyawan dengan menganalisis kepuasan pelanggan terhadap kualitas pelayanan dengan metode servqual serta IPA. Penelitian dilakukan di PDAM dimana PDAM harus memberikan pelayan jasa terbaik kepada pelanggannya. Hasil penelitian berdasarkan hasil perhitungan, terjadi adanya kesenjangan antara jasa yang dirasakan dari segi persepsi konsumen dan jasa yang diharapkan atau ekspektasi konsumen pada semua dimensi kualitas pelayanan yaitu dimensi tangibles, reliability, responsiveness, assurance, emphaty yang ada di PDAM sehingga pihak PDAM harus memperbaiki dimensi tersebut sehingga sesuai dengan harapan konsumen [5].

Helmi dkk melakukan penelitian untuk mengetahui kualitas pelayanan izin trayek oleh Dinas Lalu Lintas Angkutan Jalan DLLAJ di Kabupaten Bogor. Pendekatan yang digunakan dalam penelitian ini yaitu dengan survey, jenis dari penelitian menggunakan metode deskriptif yaitu penelitian dengan menggunakan variabel mandiri, baik satu variabel atau lebih tanpa membuat perbandinganan. Hasil dari penelitian yaitu persepsi masyarakat terhadap trayek tersebut sangat puas [6].

Pambudi melakukan penelitian pada SBU Laboratory Cibitung PT Sucofindo (Persero) yang dianggap belum maksimal dan belum memuaskan hasrat pelanggan, sehingga dianalisis faktor atau atribut yang mempengaruhi layanannya. Dari jumlah 35 atribut yang termasuk pada 7 variabel terdapat dua hal penting yang perlu di tingkatkan yaitu atribut biaya sehingga dapat sesuai dengan keinginan pelanggan [7].

Hidayat, dkk dengan menganalisis kepuasan pengguna layanan TIK di Universitas Siliwangi. Analisis dilakukan karena UPT. TIK harus mengukur layanan apakah sudah sesuai dengan yang diinginkan oleh pengguna. Hasil penelitian menunjukkan bahwa UPT.TIK belum mampu untuk memberikan pelayanan bagi civitas akademika di Universitas Siliwangi. Hal tersebut dikarenakan kurangnya SDM bidang TI dan belum mampu terpenuhinya personil TI sesuai dengan tata kelola kerja [8].

Noer melakukan penelitian mengenai penerapan metode servqual serta IPA dalam menentukan kualitas pelayanan mahasiswa magister manajemen teknologi ITS Surabaya. Hasil penelitian menunjukkan terdapat beberapa atribut layanan yang masih perlu diperbaiki seperti tempat parkir, kesigapan petugas, kemudahan mahasiswa dalam menyampaikan keluhan [9].

Syukhri melakukan penelitian pada kepuasan mahasiswa terhadap pelayanan laboratorium. Atribut pelayanan yang perlu untuk diperbaiki yaitu kondisi ruang laboratorium yang kurang nyaman, akses internet yang kurang baik, kualitas hardware yang kurang baik, keramahan teknisi laboratorium, sulitnya mahasiswa dalam memperoleh pelayanan yang baik, serta yang terakhir yaitu sulitnya untuk menghubungi teknisi laboratorium [10].

Wibowo dan Ardhi menganalisa tingkat kepuasan konsumen terhadap kualitas layanan pada Minimarket SK. Karakteristik umum dari UKM yaitu lemah dalam hal pengelolaan pelanggan. Minimarket SK belum melakukan evaluasi terhadap layanan sehingga perlunya dilakukan analisis mengenai kualitas pelayanan yang diberikan kepada pelanggan apakah telah sesuai dengan harapan pelanggan. Hasil yang didapat setelah melakukan perhitungan dengan menggunakan metode Servqual dan IPA yaitu terdapat beberapa atribut yang perlu untuk diperbaiki yaitu pembayaran yang dilakukan harus menggunakan debit, fasilitas tempat duduk, ketersediaan barang, dapat melakukan pembayaran transaksi belanja online dan komunikasi terhadap pelanggan perlu untuk ditingkatkan [11].

Winanda dan Sriyanto melakukan penelitian dengan menganalisis kualitas dari layanan restoran cepat saji dengan menggunakan metode servqual dan IPA. Penelitian ini menggunakan dimensi pada metode servqual yaitu dimensi tangible, reliability, responsiveness, assurance, dan empathy kemudian digunakan metode IPA untuk menentukan prioritas atribut layanan yang perlu untuk diperbaiki. Hasil yang didapat yaitu adanya gap negatif yang berarti pelanggan masih belum merasa puas akan pelayanan yang diberikan. Nilai gap negatif tertinggi yaitu berada pada dimensi tangible mengenai pelayanan jumlah kasir yang masih kurang karena seringnya terjadi penumpukan jumlah antrian sehingga perlunya dilakukan prioritas perbaikan pada atribut pelayanan tersebut [12].

Rachmadita dan Arninputranto membahas mengenai analisis kepuasan pelanggan pada kualitas pelayananan perpustakaan di perguruan tinggi dengan metode servqual serta IPA. Analisa dilakukan dengan cara menemukan gap antara persepsi pelanggan dan harapan pelanggan. Hasil analisis menunjukkan bahwa kelima dimensi layanan bernilai negatif terutama pada atribut layanan untuk menyediakan katalog sehingga mudah untuk diakses yang perlu untuk diprioritaskan untuk diperbaiki [13].

p-ISSN:1693 - 2951; e-ISSN: 2503-2372

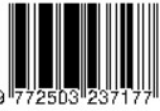


Ariyanto dkk meneliti kualitas pelayanan jasa dengan menggunakan metode servqual dan IPA di bengkel AHASS. Penelitian dilakukan untuk dapat mengetahui tingkat kepuasan dari pelanggan dan mengetahui pelayanan yang perlu untuk diperbaiki. Hasil dari penelitian yaitu dari 25 atribut layanan dengan 15 atribut yang memiliki nilai gap negatif. Sehingga kualitas pelayanan pada bengkel AHASS masih belum memenuhi keinginan pelanggan dan perlu untuk diperbaiki [14]

Nusaputra dkk melakukan penelitian mengenai kualitas layanan pada bengkel dengan menggunakan metode servqual serta IPA. Berdasarkan kuesioner terdapat beberapa keluhan yang diberikan pelanggan kepada pihak bengkel sehingga perlunya untuk dilakukan suatu perbaikan layanan. Salah satu keluhan yang dialami pelanggan yaitu saat melakukan service yang memakan waktu cukup lama sehingga untuk atribut ini perlu diprioritaskan untuk diperbaiki [15].

Muktiyono meneliti kualitas layanan yang diberikan oleh unit BPP Enginering melalui cara mengintegrasikan 2 metode yaitu metode servqual dan pengukuran IPA. Penelitian dilakukan karena BPPT merupakan badan pusat pelayanan teknologi harus memberikan layanan yang baik kepada pelanggan sehingga perlunya dilakukan pengawasan dan analisa terhadap layanan tersebut [16].

Yana dkk melakukan penelitian mengenai kepuasan dari masyarakat terhadap layanan pada Dinas PTSP Denpasar dengan menggunakan metode servqual dan IPA untuk mengetahui kualitas layanannya. Hasil dari penelitian ini yaitu terdapat 7 atribut layanan yang diprioritaskan untuk diperbaiki. Beberapa upaya yang dilakukan untuk meningkatkan pelayanannya yaitu dengan mengadakan pelatihan bagi pegawai, penambahan kursi pada tempat tamu, pemeriksaan dokumen, sosialisasi, dan memberikan hukuman bagi yang melanggar [17].

Deo melakukan penelitian untuk menganalisis kualitas layanan pada aplikasi lazada. Penelitian menggunakan dua metode yaitu metode servqual dan metode IPA. Dilakukannya penelitian karena masih banyak pelanggan yang mengeluh terhadap layanan yang diberikan. Hasil yaitu adanya 5 layanan yang perlu untuk diperbaiki segera yang sangat berpengaruh terhadap pelanggan [18].

Prananda dkk melakukan analisis dengan menggunakan IPA dan metode servqual terhadap kualitas layanan yang diberikan kepada pelanggan. Penelitian dilakukan di Hotel untuk meningkatkan kepuasan pelanggan kepada pelanggan hotel. Hasil dari penelitian yaitu dari setiap dimensi servqual menunjukkan bahwa dimensi tangibles merupakan dimensi yang memiliki nilai kualitas terkecil sehingga perlu adanya perbaikan [19].

Putri dkk menganalisis penerapan metode servqual dan Quality Funcion Deployment (QFD) untuk mengetahui layanan yang ada di PT. KAI dengan mengambil data penumpang tahun 2017. Hasil analisis yaitu layanan yang ada pada tingkatan sedang. Rencana perbaikan yaitu kesiapan dalam memberikan tangga bantuan yang berada pada tingkat ketidakpuasan yang tinggi oleh penumpang [20].

Umam dan Hariastuti melakukan penelitian dengan menerapakan metode IPA dan CSI untuk menganalisis kepuasan pelanggan serta untuk mengetahui prioritas layanan yang berpengaruh terhadap pelanggan. Terdapat 3 atribut yang menjadi prioritas untuk diperbaiki. Layanan tersebut yaitu variasi pilihan jasa fotografi, lamanya waktu tunggu hasil cetak foto, dan kemampuan karyawan dalam memahami keinginan pelanggan [21].

Mahardi dkk melakukan penelitian untuk mengukur kualitas layanan dari bus di Surabaya. Tujuan analisis yaitu untuk mengetahui layanan yang harus diprioritaskan kepada penumpang sehingga meningkatkan kepuasan dari penumpang tersebut. Hasil dari penelitian ini yaitu tidak ada satupun layanan yang memenuhi keinginan penumpang. Aspek yang perlu untuk diperbaiki yaitu tentang ketersediaan layanan Air Conditioner yang masih jauh dari harapan penumpang [22].

Mariska dan Shihab membahas mengenai tingkat kepuasan tamu hotel yang ada di Jakarta dengan menggunakan metode IPA serta servqual. Hasil pengukuran Servqual yaitu dengan melihat dimensi servqual yang menunjukkan bahwa belum maksimal atau masih belum sesuai dengan harapan pelanggan. [23].

Febrianto dan Khabibah menganalisis pengaruh kepuasan pengguna dengan menggunakan metode IPA yang dilakukan pada website Blossom Game Store Malang. Layanan yang harus diperbaiki yaitu kualitas website meliputi kemudahan navigasi, relevan, detail, dan akurat [24].

Lusianti dan Alifiana melakukan penelitian dengan menggunakan metode IPA. Penelitian ini dilakukan untuk menganalisis kepuasan dari mahasiswa. Atribut layanan yang perlu untuk segera diperbaiki yaitu berjumlah 4 atribut layanan Aspek yang perlu diperbaiki yaitu mengenai lokasi serta fasilitas dari kampus [25].

Review penelitian diatas menunjukkan bahwa pendekatan servqual, IPA telah mampu untuk mengukur tingkat layanan yang diberikan. Metode servqual digunakan untuk menjabarkan atribut layanan yang ada untuk mendapatkan data berupa nilai persepsi dan harapan pelanggan. Sedangkan IPA bertujuan menjabarkan atribut layanan tadi kedalam kuadran sehingga dapat diketahui atribut layanan yang harus segera untuk diperbaiki. Hasil pengukuran berdasarkan pada penelitian diatas menunjukkan masih banyaknya atribut layanan yang belum sesuai dengan harapan pelanggan yang harus diperbaiki. Secara umum faktor yang mempengaruhi ketidakpuasan pelanggan yaitu kurangnya faktor internal maupun eksternal dalam menanggapi permintaan pelanggan sehingga membuat kurang merasa puas akan layanan yang didapatkan oleh pelanggan.

Penerapan dari metode servqual dan IPA telah digunakan pada beberapa penelitian seperti pada review diatas, penelitian tersebut dilakukan mulai dari tahun 2014 sampai 2020. 


\section{Jumlah Penelitian dengan Metode} Servqual dan IPA di Indonesia

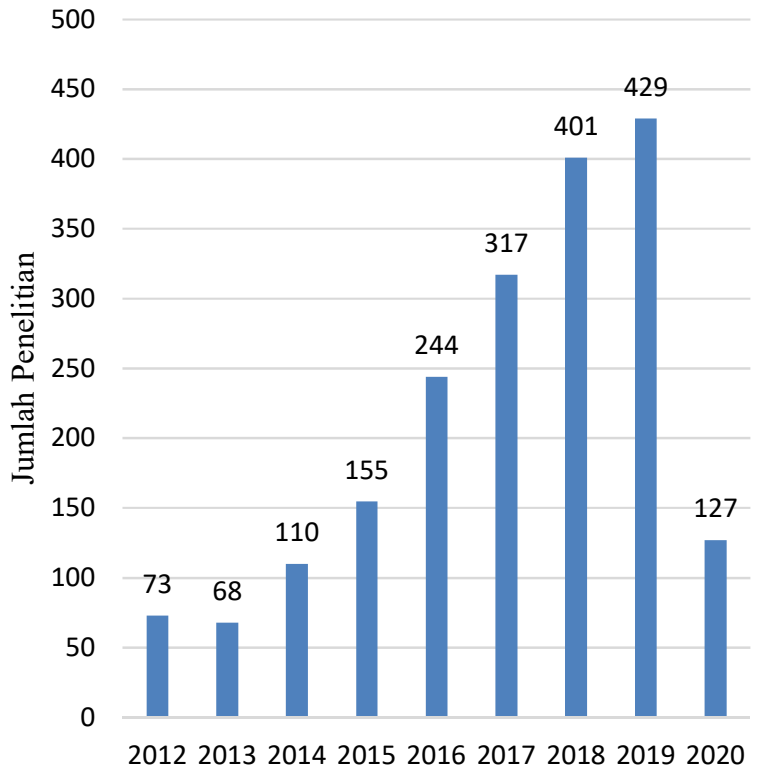

Tahun

Gambar 3. Jumlah Penelitian dengan Metode servqual dan IPA di Indonesia

Gambar 3 menunjukkan perkembangan penelitian yang dengan metode servqual, IPA dalam mengukur tingkat layanan yang ada di Indonesia pada tahun 2012 - 2020. Grafik menunjukkan bahwa penerapan dengan penggabungan metode servqual dan IPA dari tahun 2012 ke tahun 2013 adanya penurunan jumlah penelitian tetapi setelah tahun 2013 keatas adanya kenaikan sampai tahun 2019. Hal tersebut berarti metode servqual dan IPA telah berhasil dalam mengukur tingkat kepuasan layanan pelanggan sehingga metode tersebut terus digunakan sampai sekarang.

Berdasarkan pada penelitian diatas, penerapan dari metode servqual dan IPA diterapkan pada beberapa lembaga baik pemerintahan maupun swasta. Lembaga-lembaga tersebut menggunakan metode servqual dan IPA dalam membantu menemukan kualitas dari layanan dan menemukan layanan yang belum sesuai dengan harapan dari pelanggan sehingga dapat segera untuk diperbaiki.

Penelitian yang dilakukan sebelumnya dapat dirangkum dalam sebuah diagram untuk mengetahui tingkat penggunaan dari metode servqual dan IPA tersebut lebih banyak diterapkan pada lembaga apa saja. Rangkuman penerapan metode servqual dan IPA tersebut dapat didigambarkan dalam bentuk diagram berikut.

I Putu Astya Prayudha : Review Literatur Tentang Analisis...

\section{Penerapan Metode Servqual dan IPA pada Lembaga Pemerintahan dan Swasta}

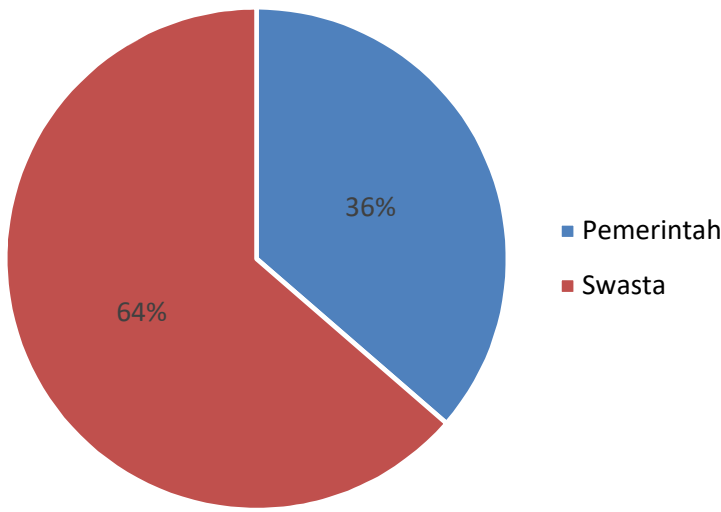

Gambar 4. Diagram penerapan Metode Servqual dan IPA pada Lembaga

Gambar 4 merupakan pembagian penggunaan dari metode servqual dan IPA pada penelitian yang telah dibahas sebelumnya. Diagram diatas menunjukkan bahwa lembaga swasta merupakan lembaga yang paling banyak menggunakan metode servqual dan IPA untuk mengetahui tingkat layanan perusahaannya. Metode servqual dan IPA yang diterapkan tersebut telah mampu membantu dalam mencari layanan yang dianggap kurang atau yang masih belum sesuai dengan harapan pelanggan.

Terdapat dua nilai yang penting didalam setiap penelitian tersebut yaitu nilai prioritas perbaikan dan nilai sesuai harapan. Nilai-nilai tersebut merupakan nilai yang menjadi hasil akhir didalam penelitian dengan menggunakan metode servqual dan IPA. Hasil nilai prioritas perbaikan dan nilai sesuai harapan yang ada pada tiap penelitian. 


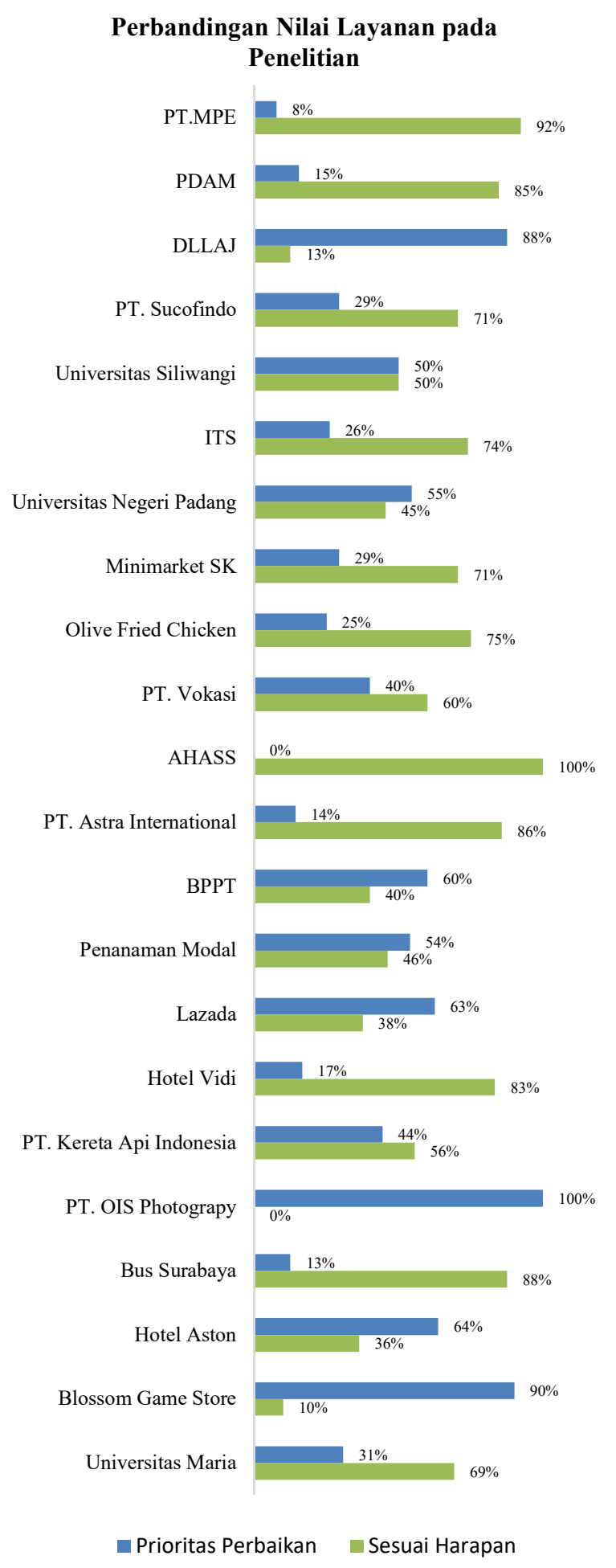

Gambar 5. Perbandingan Nilai Layanan

Gambar 5 adalah hasil rekapan berdasarkan penelitian yang telah dibahas sebelumnya yang menunjukkan perbandingan nilai yang didapat setelah memasukkan nilai persepsi dan harapan kedalam kuadran IPA. Terdapat dua nilai yaitu nilai prioritas perbaikan dan nilai sesuai harapan. Nilai prioritas perbaikan merupakan jumlah atribut layanan yang segera harus diperbaiki sedangkan nilai sesuai harapan merupakan atribut layanan yang sudah sesuai dengan harapan dari pelanggan sehingga perlu untuk dipertahankan.

Hasil nilai prioritas perbaikan tertinggi yaitu penelitian pada PT. OIS Photograpy dimana penelitian tersebut memiliki nilai prioritas perbaikan sebanyak $100 \%$ dari semua atribut layanan yang digunakan. Hasil tersebut menunjukkan bahwa semua layanan yang ada belum sesuai dengan keinginan pelanggan sehingga perusahaan harus segera meningkatkan dan memperbaiki layanan tersebut.

Hasil nilai sesuai harapan tertinggi yaitu penelitian pada AHASS yang berarti bahwa semua atribut layanan yang diterapkan telah mampu memenuhi keinginan pelanggan atau dengan kata lain pelanggan telah puas akan layanan yang diberikan oleh perusahaan sehingga semua layanan tersebut harus dipertahankan.

Untuk melihat tingkat layanan pada lembaga berdasarkan pada nilai prioritas perbaikan dan nilai sesuai harapan diatas maka dapat disimpulkan dalam diagram berikut.

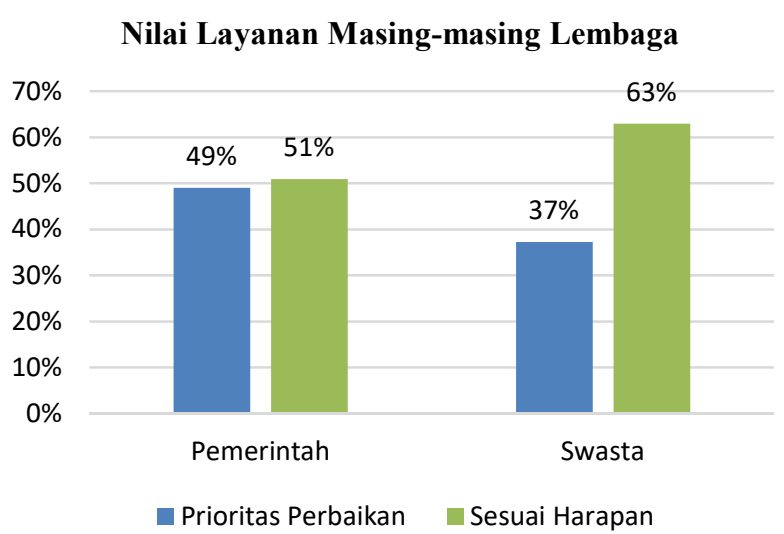

Gambar 6. Nilai Layanan Masing-masing Lembaga

Gambar 6 merupakan rangkuman dari nilai rata-rata prioritas perbaikan dan sesuai harapan dari semua penelitian diatas yang dikategorikan berdasarkan lembaga. Dapat dilihat bahwa lembaga pemerintah memiliki prioritas perbaikan $49 \%$ dan nilai sesuai harapan 51\%. Hal tersebut menandakan bahwa setengah dari layanan yang diberikan masih perlu untuk segera diperbaiki. Sedangkan pada swasta untuk keseluruhan masih dominan pelanggan masih puas akan layanan yang diberikan meski ada beberapa layanan yang perlu untuk segera diperbaiki dengan nilai sesuai harapan $63 \%$ dan prioritas perbaikan $37 \%$.

B. Kekurangan dari Hasil Penelitian Sebelumnya

Berdasarkan pada beberapa penelitian yang telah dibahas diatas dengan penelitian menggunakan metode servqual atau IPA yang digabungkan dengan metode lain yang mayoritas merupakan metode yang digunakan dalam penjabaran atribut layanan untuk mengetahui nilai layanan pada sebuah perusahaan, tetapi pada penelitian tersebut dapat ditemukan 
Majalah Ilmiah Teknologi Elektro, Vol. 20, No. 2, Juli-Desember 2021

DOI: https://doi.org/10.24843/MITE.2021.v20i02.P04

beberapa kelemahan atau kekurangan jika menggunakan metode tersebut. Walaupun penggunaan dari metode servqual telah mampu menjabarkan atribut layanan dan memperbaikinya berdasarkan pada diagram kartesius IPA tetapi metode tersebut belum menyediakan mapping solusi yang disarankan berdasarkan pada atribut layanan yang masih kurang atau perlu diperbaiki. Sehingga saat hasil atribut layanan yang kurang atau yang perlu diperbaiki telah diketahui dalam sebuah perusahaan, solusi perbaikan langsung diberikan oleh pihak perusahaan. Jika ada sebuah metode atau cara yang dikombinasikan kedalam metode servqual dan IPA maka hasil perbaikan tentunya akan lebih efektif dan maksimal.

\section{KESIMPULAN}

Kesimpulan review diatas yaitu metode servqual dan IPA sudah banyak digunakan untuk mengetahui tingkat kepuasan layanan yang dirasakan pelanggan. Metode servqual digunakan untuk mengelompokkan atribut layanan pada sebuah perusahaan kedalam dimensi servqual. Metode IPA digunakan sebagai pengelompokkan atribut layanan kedalam empat kuadran. Hasil dari analisis diketahui bahwa layanan pada lembaga swasta lebih baik dalam memberikan kepuasan kepada pelanggannya dengan nilai $63 \%$ dibandingkan pada lembaga pemerintah hanya dapat memberikan nilai $51 \%$.

\section{REFERENSI}

[1] T. Rachman, D. Wahyuningsih, And M. Rahman, "Model Integrasi Metode Servqual Dan Importance Performance Analysis (Ipa) Untuk Penentuan Prioritas Perbaikan Pelayanan Administrasi Di Perguruan Tinggi," Jurnal Inovisi, Vol. 14, No.2, 2018.

[2] A. Gani And L. A. Utami, "Penerapan Metode Webqual 4 . 0 Dan Ipa Dalam Mengukur Kualitas Website Vislog Pt. Citra Surya Indonesia Application Of Webqual 4 . 0 And Ipa Methods In Measuring Quality Of Vislog Website Pt . Citra Surya Indonesia," Vol. 9, No. 28, Pp. 25-34, 2020.

[3] D. Vanesa, F. Firman, And H. A. Mesta, "Analisis Peningkatan Kualitas Pelayanan Pasien Menggunakan Metode Servqual Dan Importance Performance Analysis (IPA)," Jurnal Kajian Manajemen Dan Wirausaha, Vol. 2, No. 1, P. 28, 2020.

[4] A. Winarno, "Analisis Kualitas Pelayanan Terhadap Pelanggan Dengan Metode Service Quality (Servqual) Dan Importance Performance Analysis (Ipa)," IEEE Commun. Surv. Tutorials, Vol. 15, No. 4, Pp. 20462069, 2018.

[5] W. Setyawan, "Analisis Kepuasan Pelanggan Terhadap Kualitas Pelayanan Menggunakan Metode Service Quality Dan Importance Performance Analysis ( Studi Kasus Di Kantor Pdam Kabupaten Cianjur )," Vol. 3, No. 1, Pp. 80-86, 2017.

[6] T. Helmi, R. A. Munjin, And I. Purnamasari, "Kualitas Pelayanan Publik Dalam Pembuatan Izin Trayek Oleh Dllaj Kabupaten Bogor," Jurnal Governansi, Vol. 2,
No. 1, P. 51, 2017.

[7] J. O. Ong And J. Pambudi, "Analisis Kepuasan Pelanggan Dengan Importance Performance Analysis Di Sbu Laboratory Cibitung Pt Sucofindo (Persero)," J@Ti Undip Jurnal Teknik Industri, Vol. 9, No. 1, Pp. 1-10, 2014.

[8] R. Hidayat, Maulana, “Analisis Service Quality Untuk Mengukur Tingkat Kepuasan Pengguna Layanan Tik Di Universitas Siliwangi," Seminnar Nasional Teknologi Informasi Dan Multimedia 2017, Pp. 25-30, 2017.

[9] L. R. Noer, “Analisis Peningkatan Kualitas Pelayanan Mahasiswa Magister Manajemen Teknologi Its Surabaya Dengan Metode Servqual Dan Importance Performance Analysis (Ipa)," Journal of Research and Technologies, Vol. 2, No. 1, Pp. 35-43, 2016.

[10] S. Syukhri, "Analisis Kepuasan Mahasiswa Terhadap Pelayanan Laboratorium Jaringan Menggunakan Pendekatan Importance-Performance Analysis," Jurnal Inovasi Vokasional dan Teknologi Volume, Vol. 18, No. 2, Pp. 109-114, 2018.

[11] T. J. Wibowo And M. N. Ardhi, "Analisis Tingkat Kepuasan Konsumen Terhadap Kualitas Layanan Pada Minimarket Sk," Jurnal Ilmiah Teknik Industri dan Informasi, Vol. 8, No. 1, Pp. 34-49, 2019.

[12] A. Winanda And S. Sriyanto, "Analisis Kualitas Pelayanan Restoran Cepat Saji Dengan Metode Servqual (Service Quality) Dan Ipa (Importance Performance Analysis) (Studi Kasus Restoran Olive Fried Chicken)", Vol. 5, No. 4, Pp. 1-6, 2016.

[13] R. N. Rachmadita And W. Arninputranto, "Analisis Kepuasan Pemustaka Terhadap Kualitas Layanan Perpustakaan Di Perguruan Tinggi Vokasi Dengan Metode Servqual Dan Importance-Performace Analysis," Berkala Ilmu Perpustakaan dan Informasi, Vol. 14, No. 2, P. 214, 2018.

[14] Ariyanto dkk, "Kualitas Pelayanan Jasa Menggunakan Metode Servqual Dan Importance Performance Analysis", Jurnal Bina Darma Conferenceon Engineering Science.

[15] L. T. W. N. K. Naufal Nusaputra, Mochamad Choiri, “Analisis Peningkatan Kualitas Pelayanan Bengkel Dengan Metode Servqual, Ipa, Dan Indeks Pgev ( Studi Kasus Di Pt . Astra International Tbk-Daihatsu Branch Office Malang) Analysis Of Quality Improvement Services Workshop By Using Servqual, Ipa , And Pg," Jurnal Rekayasa Dan Manajemen Sistem Industri, Vol. 2, No. 6, Pp. 1239-1250.

[16] Paul M. Muchinsky, "Rancangan Kualitas Pelayanan Unit Bppt Enjiniring Dengan Integrasi Servqual, Ipa Dan Kano Model Dalam Model QFD”, Jurnal OE No. 9, Pp. 1689-1699, 2012.

[17] P. Studi, M. Teknik, S. Fakultas, T. Universitas, And U. Denpasar, "Analisis Kepuasan Masyarakat Terhadap Kualitas Pelayanan Izin Mendirikan Bangunan ( IMB )

$$
\text { p-ISSN:1693 - 2951; e-ISSN: 2503-2372 }
$$

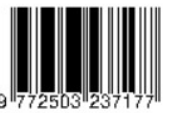


Pada Dinas Penanaman Modal Dan Pelayanan Terpadu

Satu Pintu Kota Denpasar Anak Agung Gde Agung

Yana , I Nyoman Sutarja, Dan Putu Lissa

Ambarawangi The Analysis Of P," Vol. 8, No. 1, Pp. 45-53, 2020.

[18] P. G. E. Deo, "Analisis Kualitas Layanan Lazada Dengan Menggunakan Metode E-Servqual Dan Ipa," Journal Accounting Bussiness Study, Vol. 2, No. 1, Pp. 1-19, 2017.

[19] Y. Prananda, D. R. Lucitasari, And M. S. Abdul Khannan, "Penerapan Metode Service Quality (Servqual) Untuk Peningkatan Kualitas Pelayanan Pelanggan," Opsi, Vol. 12, No. 1, P. 1, 2019.

[20] S. I. Putri, S. Sumartini, And A. Sofia, "Metode Service Quality (Servqual) Dan Quality Function Deployment (Qfd) Sebagai Usulan Perbaikan Kualitas Pelayanan Di Pt. Kereta Api Indonesia (Persero)," Jurnal Ilmu Manajemen Dan Bisnis, Vol. 8, No. 1, P. 11, 2017.

[21] R. K. Umam And N. P. Hariastuti, "Analisis Kepuasan Pelanggan Dengan Menggunakan Metode Customer Satisfaction Index (CSI) Dan Importance Performance Analysis (Ipa)," Seminnar Nasional Sains Dan Teknologi Terapan, Pp. 339-344, 2018.

[22] P. Mahardi, T. Sudibyo, And F. R. Widayanti, "Analisis Kualitas Pelayanan Bus Kota Surabaya Berdasarkan Persepsi Pengguna Dengan Metode Importance Performance Analysis ( IPA )," Ijocet, Pp. 22-29, 2008.

[23] Z. Mariska And M. Shihab, "Pengaruh Dimensi Service Quality Terhadap Kepuasan Tamu Hotel Dan Dampaknya Terhadap Behaviour Intention (Studi Kasus Pada Hotel Aston Kuningan Suites-Jakarta)," Jurnal Manajemen Dan Bisnis Sriwijaya, Vol. 14, No. 2, Pp. 217-234, 2016.

[24] M. Febrianto Et Al., "Pengaruh Usability, Information Quality, Dan Service Interaction Quality Terhadap Kepuasan Pengguna Dan Metode Importance Performance Analysis ( IPA )" Jurnal Bisnis, Vol. 5, No. 1, Pp. 1-4, 2019.

[25] S. Agus, S. Abdul, And H. Ika, "Jurnal Ilmiah Mahasiswa Manajemen Dan Bisnis," Vol. 2, No. 1, Pp. 1-12, 2019. 